\title{
Risk Assessment for Hexamine Nitration into RDX
}

\author{
Erick Braga Ferrão Galante1, Daniele Mesquita Bordalo da Costa², Assed Naked Haddad², \\ Isaac José Antônio Luquetti dos Santos ${ }^{3}$
}

\begin{abstract}
Explosives are widely used in extraction of ores, melts and fuels and in the safe and economical demolition of structures. These applications demonstrate the value of explosives to society and the reason why they are manufactured worldwide despite the hazard of their preparation. Hence, this paper focuses on the manufactory of the military explosive Hexogen (also known as RDX). The characteristics of the process are described by the analysis of a specify manufactory plant. The chosen analysis tool is the Hazard and Operability Study - HazOp. Historically, this methodology has been applied at chemical industries and is used in industrial process operability analysis. This study analyses seven critical nodes in the RDX manufacturing process, identifies several deviations, and causes and consequences. From these results, improvements in the units are suggested and actual conditions discussed. It is important to remark that this work is an initial approach to analysis of the manufacturing process of RDX using the HazOp methodology.
\end{abstract}

KEYWORDS: Risk Assessment, Explosives, Nitration, Hexogen, RDX, HazOp.

\section{INTRODUCTION}

Explosives are energetic materials that have been used since the basic foundations of modern civilization in minerals, ores, metals and fuel exploitation. Due to their importance, explosives are manufactured worldwide. Every operation involving explosive usage offers risks. Hexogen (also known as RDX) is a high explosive, largely used in the oil industry (Galante et al., 2013). Hence, the risk of explosion is always present in production processes (Khan and Abbasi, 1999), which may lead to large accidents, such as the one in Bhopal (Bisarya and Puri, 2005; Chouhan, 2005; Eckerman, 2005; Gehlawat, 2005). An "explosive" is defined as solid or liquid substances that can combust quickly in an exothermic reaction (Meyer et al., 2007). Instability is a major characteristic of explosives, which undergo reaction triggered by flame, friction or heat. A quick release of gases at high-pressure gases, with a great energy emission, characterizes the explosion.

Due to these characteristics, the manufacture, testing, sale, storage, and transportation of explosives require special consideration, which can be addressed by performing risk analyses, shuck as HazOp or Hazard Preliminary analyses. According to Taylor (2007), design issues can be addressed during any stage of a chemical unit, even one already operating. From that perspective, this work assesses the existing risks at a nitration process in the manufacture of RDX, emphasizing the perspective presented by Steen and Aven (2011), who discusse engineering risks. From the works of Aven (2012) and Held (2012), one realizes that a risk analysis of a RDX manufacturing unit is feasible through HazOp methodology. Furthermore, Held (2012) reported and discussed detonation of a small amount

\footnotetext{
三 1. Instituto Militar de Engenharia - Rio de Janeiro/RJ - Brazil 2.Universidade Federal do Rio de Janeiro - Rio de Janeiro/RJ - Brazil 3.Comissão Nacional de Energia Nuclear - Rio de Janeiro/RJ - Brazil. 
of explosive in the piping just after batch nitration of HMX. In this accident, one operator was injured with shrapnel and then hospitalized. Damage to the plant was minor. Held (2012) reported that the investigation of this accident showed that the sensitivity of intermediate products was underestimated and that a HazOp (Boonthum et al., 2014; Dunjó et al., 2010; Rausand and Hoyland, 2011; Rausand and Utne, 2009) should be used to assess risk prior to the start-up of the unit.

Hence, the main goal of this paper is to analyze and diagnose risks in a chemical unit used to manufacture RDX. Graf and Schmidt-Traub (2000), among others, proposed the use of $\mathrm{HazOp}$ for addressing safe operation of chemical plants, which in this particular case is a unit to nitrate Hexamine into RDX. Therefore, the HazOp was chosen as the most suitable method for this paper.

\section{CASE OF STUDY}

Explosives are substances of great importance in human development. Besides their traditional use by the military, RDX is used in civilian applications, such as tunnels, construction, and exploitation of natural resources such as mining and oil exploration. Explosives are chemical substances or mixtures of substances, which react rapidly by heating or attrition and generate large volumes of gas and heat. Explosives are classified by several standards (for example STANAG (NATO), MILSTD (USA) and TM-9-1903 (USA)). Classifying explosives according to their detonation velocity is far common. RDX is classified as a high explosive (also known as "secondary explosive") due to its output of energy during detonation, when compared to a low explosive (with a detonation velocity in the same magnitude of the speed of sound) (Akhavan, 2011; Cooper, 1996; Galante et al., 2014; Meyer et al. , 2007; Urbanski, 1984).

Hexogen, RDX, T4 or cyclone are common names for 1,3,5-trinitroperhydro-1,3,5-triazine. Hexogen is an explosive used as main charge in military warheads, as well as in mining explosives (Galante et al., 2013; Galante and Haddad, 2009) or additive to propellants. It is soluble in acetone, insoluble in water, and partly soluble in ether and ethanol. According to Meyer et al. (2007), RDX may be the most important explosive in terms of brisance; besides that, its explosive power is high, as well as its detonation velocity (Mei et al., 2012).
Due to the inherent risk contact, it is necessary to observe $\mathrm{RDX}$ storage and transport conditions. This explosive is very sensitive to electrical sparks, shock, and heat and impact, among some other stimuli. Achuthan and Mullick (1983) studied and discussed risks including fire, explosion, and toxic hazards during manufacture of RDX.

\section{PRODUCTION PROCESS}

Bachmann and Sheehan (1949); Leach and Staples (1981); Lukasavage and Slagg (1993) and Meredith (1976) were the first to describe the synthesis of the high explosive hexogen (RDX). The Chemical production of RDX occurs mainly in nitration vessels. Hence, this is the core of any manufacturing facility. According to the analysis of manufacturing procedures (Akhavan, 2011; Cooper, 1996; IMBEL, 2006; Lukasavage and Slagg, 1993; Meredith, 1976; Urbanski, 1984), the typical capability of production in a semi-batch type unit (Fogler, 1999) is $50 \mathrm{~kg}$ dry hexamine per hour/batch (IMBEL, 2006). The process transforms hexamine into RDX via nitration (using $\mathrm{HNO}_{3}$ ) and paraformaldehyde (the paraformaldehyde is added to the vessel manually and before the production starts).

This case of study produces Hexogen $\left(\mathrm{C}_{3} \mathrm{H}_{6} \mathrm{O}_{6} \mathrm{~N}_{6}\right)$ by nitrating hexamethylaminetriamine $\left(\mathrm{C}_{6} \mathrm{H}_{12} \mathrm{~N}_{4}\right)$ using strong nitric acid. The later precipitation of the explosive occurs by adding cold water. The industrial manufacture of RDX used for this study parallels processes patented by Luksavage and Slagg (1993) and Meredith (1976). The flowchart under study (Fig. 1) basically consists of the mixture in nitration vessels, boilers, followed by filtration of the final product. Although this is not the most recent method for manufacturing RDX, it is still largely used worldwide, reason why it was chosen for this study.

In this process, the reaction temperature is kept between $12^{\circ} \mathrm{C}$ and $15^{\circ} \mathrm{C}$ during the addition of nitric acid, the reaction is allowed to go up to $18^{\circ} \mathrm{C}$, temperature in which it is quenched. After finishing the nitration, the mixture is heated to $60^{\circ} \mathrm{C}$ for 60 minutes. After this period, the mixture is cooled and the RDX precipitate is filtered, washed and dried. Each stage (nitration, heating and cooling) is held in a different vessel. The equipment specified in Table 1, which also shows the available quantities, comprises the manufacturing facility.

All the vessels listed in Table 1 have a nominated volume of 300 liters and are made of stainless steel. Each and every vessel is equipped with a safety release valve, placed in the bottom end of the vessel. These safety valves operate under air pressure, which means that they will open if the pressure in an air pipeline 


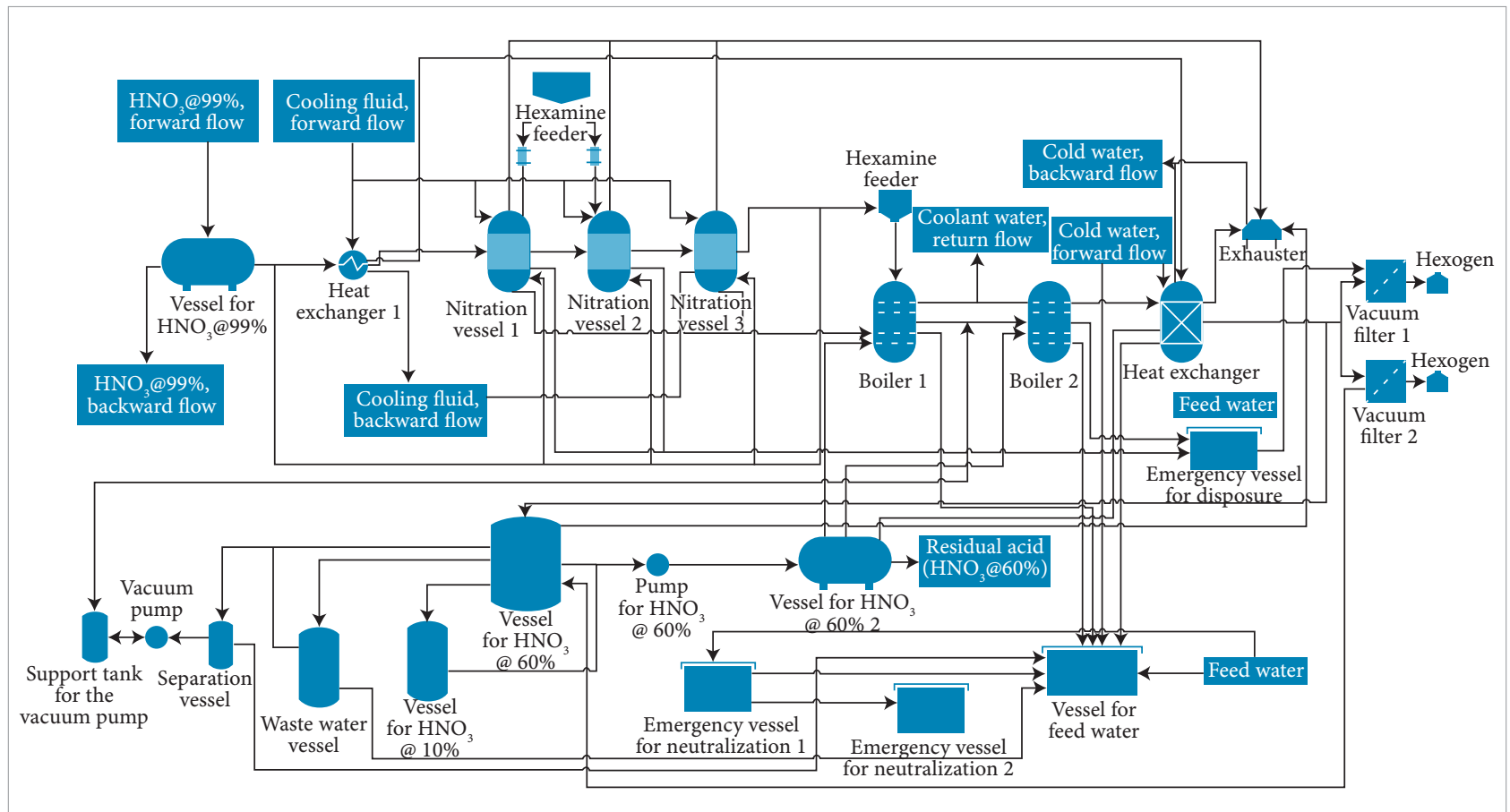

Figure 1. Production flowchart.

Table 1. Equipment list.

\section{Quantity}

1

1

1

1

3

1

2

2

3

2

1

1

1

2

1

1

2

\section{Type of equipment}

Hexamine feeder

Pump for $\mathrm{HNO}_{3} @ 60 \%$

Vacuum pump

Vessel for feed water

Hexamine rated feeder

Exhauster

Boiler

Vacuum filter

Nitration vessel

Emergency neutralization vessel

Waste water vessel

Support tank for the vacuum pump

Vessel for $\mathrm{HNO}_{3} @ 10 \%$

Vessel for $\mathrm{HNO}_{3} @ 60 \%$

Vessel for $\mathrm{HNO}_{3} @ 99 \%$

Separation vessel

Heat exchanger drops, may it be by design (operator acting upon a switch) or by a power loss in the unit. These vales will automatically open if the reaction temperature within the nitration vessel moves above $18^{\circ} \mathrm{C}$. All safety valves are connected to an emergency neutralization vessel, diluting the nitric acid will be diluted and the reaction quenched.

\section{MATERIALS AND METHODS: HAZOP}

Seccatore et al. (2013) stated that the rock blasting, carried out on every day activities in thousands of locations around the world, is a primary activity in mining and civil excavation. They stated that in blasting and mining activities, risk management in explosive operations aims personal and health safety. However, there are other risks involved in the employing of explosives. They have suggested the use of HazOp as the main risk analysis technique for deviations. HazOp is a method for risk assessment that favors the decision making for corrective actions, where applicable. In general, it involves several professionals from different specialties, in order to evaluate different aspects of the studied object and favors process industries due to the easiness of applying control points (Khan and Abbasi, 1999).

One of the first publications related to the methodology became available in 1974 and was called "Operability studies 
and hazard analysis" (Dunjó et al., 2010; Kletz, 2009). This paper provided a guide for applying the methodology created by the Chemical Industries Association in the UK in 1977. Dunjó et al. (2010) analyzed the increase in publications in subsequent years, especially between 1996 and 2000, in which more than 40 papers on the theme were published.

Initially, HazOp (Dunjó et al., 2010; Rossing et al., 2010) was developed to analyze chemical process systems (Pérez-Marin and Rodríguez-Toral, 2013; Schüller et al., 1997), but over time, its application was extended to other types of systems and complex operations of various kinds, including computer programs (Rausand and Hoyland, 2011). Galante and Haddad (2009) proposed a variation for use in the explosives industry. Furthermore, there are several approaches of this methodology, which could be used isolated or in parallel to other techniques (Boonthum et al., 2014; Van den Bosch and Weterings, 2005; CCPS, 1989; Defence, 2012; Haddad et al., 2012; Kennedy and Kirwan, 1998; Sahar et al., 2010; Schuller et al., 1997; Shimada et al., 2012).

A HazOp report may review all possible deviations, as well as their causes and consequences and proposes mitigation and active or passive protection (Labovský et al., 2007). According to Schüller et al. (1997), the soundness of the methodology is a function of the extent of the known interactions evaluated and the detail level of the analysis, and the depth of study of the identified consequences. A limitation of $\mathrm{HazO}$ is that this approach is inherently qualitative (a "diagnostic tool") (Crawley et al., 2000). Moreover, there is the difficulty to estimate the time required for a complete HazOp study (Dunjó et al., 2010; Freeman and Mcnamara, 1992; Khan and Abbasi, 1997) as well as a lack of risk acceptability criteria and international standards, as discussed by Rouhiainen \& Gunnerhed (2002) and Labovský et al. (2007).

The application of HazOp is based on the formulation of questions in a structured and systematic approach, through the appropriate use of guide words applied to critical points within the process being studied. From the guidewords and process parameters, deviations can be identified and further analyzed. Table 2 shows a series of standard guide words for basic application of $\mathrm{HazOp}$, as presented by Rausand and Hoyland (2011).

As previously stated, each guideword is applied to a process parameter to determine a deviation. Every deviation is studied. Table 3 provides possible relationships between guidewords and the consequent deviations.
Table 2. List of guide words.

\begin{tabular}{|c|c|c|}
\hline & Meaning & Example \\
\hline None & $\begin{array}{l}\text { None of the } \\
\text { objectives is achieved }\end{array}$ & No flow \\
\hline $\begin{array}{l}\text { More, } \\
\text { Bigger }\end{array}$ & $\begin{array}{l}\text { Quantitative increase } \\
\text { in a parameter }\end{array}$ & More temperature \\
\hline $\begin{array}{l}\text { Less, } \\
\text { Minor }\end{array}$ & $\begin{array}{c}\text { Quantitative decrease } \\
\text { in a parameter }\end{array}$ & Less pressure \\
\hline Part of & $\begin{array}{c}\text { Just part of the } \\
\text { objectives is achieved }\end{array}$ & Part of the yield \\
\hline Reverse & $\begin{array}{l}\text { Occurs the opposite } \\
\text { of what one expects }\end{array}$ & Reverse flow \\
\hline Other & Full replacement & Liquids in a gas pipe \\
\hline
\end{tabular}

Table 3. Deviations and parameters.

\begin{tabular}{|c|c|c|}
\hline Parameter & Guide word & Deviation \\
\hline Flow & $\begin{array}{c}\text { None, Less, } \\
\text { More, Reverse, } \\
\text { Other, Also }\end{array}$ & $\begin{array}{c}\text { None, Less, More, } \\
\text { Reverse, Other, } \\
\text { Contamination }\end{array}$ \\
\hline Pressure & More, Less & $\begin{array}{c}\text { More pressure, } \\
\text { Less pressure }\end{array}$ \\
\hline Temperature & More, Less & $\begin{array}{c}\text { Higher temperature, } \\
\text { Lower temperature }\end{array}$ \\
\hline Viscosity & More, Less & $\begin{array}{c}\text { More viscosity, } \\
\text { Less viscosity }\end{array}$ \\
\hline Reaction & None, Less, & $\begin{array}{c}\text { No reaction, } \\
\text { Reaction incomplete, } \\
\text { Intense reaction }\end{array}$ \\
\hline
\end{tabular}

\section{RESULTS}

This work is a reference for conducting further analysis in the unit by addressing a greater number of nodes. The nodes evaluated here were chosen because they are considered critical in the production sequence, following the criterion of a node before each "key" component. The component keys identified were two reaction tanks, the transfer of process fluids, product purification, cooling and output of the final product.

Therefore, for this study of HazOp, the process flowchart was divided into seven nodes, where each node was study according to the parameters presented in Table 4 . The selected nodes are listed as follows: 
- Array of vessels for waste and clean water for dilute $\mathrm{HNO}_{3}$ (Table 5);

- Connection between nitration vessels (Table 6);

- Connection between the nitration vessel and the boiler (Table 7);

- Connection between boilers (Table 8);

- Connection between boiler and heat exchanger (Table 9);

- Connection between the heat exchanger and the vacuum filter (Table 10); and

- Connection between the vacuum filter and the RDX recovery pan (Table 11).

These seven nodes were chosen in order to allow the study to focus on the most hazardous equipment within processes. It is reported in the literature (Akhavan, 2011; Cooper, 1996; IMBEL, 2013; Lukasavage and Slagg, 1993; Meyer et al., 2007; Urbanski, 1984) that the most critical operations are the nitration, followed by those dealing with heating and gaseous extraction. The study also incorporated some preparation vessels and filtering unities, due to the acid present in those equipment.

Hence, there are seven nodes selected for evaluation. The chosen parameters were: flow, pressure, temperature, and reaction. The viscosity parameter was not considered significant to the process, and therefore not used. Table 4 summarizes the parameters used for each node. The guidewords used were: none, more and less. It is important to highlight that "REVERSE" and "OTHER THAN" are not considered, since the production under study is not a flow process; instead it is organized in batches.

\section{NODE \#1}

The node \#1 includes all tanks containing water for washing and $\mathrm{HNO}_{3}$, i.e., waste water vessel, vessel for $\mathrm{HNO}_{3} @ 10 \%$ and vessel for $\mathrm{HNO}_{3} @ 60 \%$. These were analyzed for flow, pressure and temperature. Since the process at this node is the dilution of $\mathrm{HNO}_{3}$ and no chemical reaction occurs, the parameter "reaction" was not considered. Table 5 is the result of the HazOp for this node.

Regarding the results for the parameter "flow", there is the need to install a valve that allows the flow to increase (in cases where there is no flow or low flow) or to stop (when flow is increased). From the analysis of the parameter "pressure", the final recommendation is to install a regulatory valve at the flow into the tanks, allowing consequently the increase or decrease in pressure. Accompanying this parameter is the suggestion to install a pressure gauge to monitor it. Furthermore, one can
Table 4. Parameter used in each node.

\begin{tabular}{|c|c|}
\hline Node & Parameter \\
\hline 1 & Flow, Pressure, Temperature \\
\hline 2 & Flow, Temperature, Reaction rate \\
\hline 3 & Flow, Temperature, Reaction rate \\
\hline 4 & Flow, Pressure, Temperature \\
\hline 5 & Flow, Pressure, Temperature \\
\hline 6 & Flow, Temperature \\
\hline 7 & Flow, Temperature \\
\hline
\end{tabular}

determine deviations in temperature via thermocouples installed in the tanks (monitored via a control panel). As a solution, it is possible to increase or decrease the flow, depending on the temperature. One solution to the problem is to correlate this assembly to the heat exchanger or the inflow of brine.

\section{NODE \#2}

The second node (node \#2) connects nitration vessels 2 and 3 . For this node, the parameters flow, temperature and reaction were analyzed. Table 6 is the result of the HazOp for this node.

The pressure switch was not evaluated since its variation results from changing other parameters, making its analysis therefore redundant. Possible variations in the mass flow were analyzed using keywords "none" and "less". All of them are related to errors in hexamine dosing and possible flaws in this operation. In order to minimize the occurrence of this event, implementing automatic control in this equipment is suggested. Regarding the parameter "flow", there is also the possibility of potential physical damage to the pipes, occurring in the guidewords "none" and "less". In these cases, the implementation of a program of preventative maintenance or replacement of the pipelines, when necessary, is recommended.

In the case of increased flow ("more flow"), venting the equipment in order to prevent overpressure and the consequent risk of explosion is recommended. For this, it is necessary to empty the tank. Draining is possible through bottom discharge valves. Variation in flow is identifiable by checking discharge into the emergency vessel, which may interrupt the chemical reaction. This tank is connected to the output of all the reactors (nitration vessel and boilers). When the temperature increases above the set points (which are established from the safety limits of the reactions), the control system interrupts the supply of 
Table 5. Node \#1 - Array of vessels for waste and clean water to dilute $\mathrm{HNO}_{3}$.

\begin{tabular}{|c|c|c|c|c|c|}
\hline Guide word & Deviation & Cause & Detection & Consequences & Mitigation \\
\hline \multirow{5}{*}{ Flow } & None & \multirow{5}{*}{$\begin{array}{l}\text { Vacuum filter } \\
\text { malfunctioning } \\
\text { Defect in } \\
\text { the tank for } \\
\text { emergency } \\
\text { transfer }\end{array}$} & \multirow{4}{*}{$\begin{array}{l}\text { Indication in the } \\
\text { flow meter } \\
\text { Visual inspection } \\
\text { Under } \\
\text { functioning } \\
\text { pump to } \\
\mathrm{HNO}_{3} @ 60 \%\end{array}$} & $\begin{array}{l}\text { Breaking the vacuum pump } \\
\text { Reduced yield factor for nitration }\end{array}$ & \multirow{4}{*}{$\begin{array}{l}\text { Flow reversal of the } \\
\text { tank to the vacuum } \\
\text { pump and boiler } 2 \\
\text { through valves } \\
\text { Flow increase for the } \\
\text { tank to } \mathrm{HNO}_{3}, 60 \% \\
\text { through valves }\end{array}$} \\
\hline & & & & $\begin{array}{l}\text { Failure separation tank } \\
\text { Flow Increase for the } \\
\text { baffle for wastewater }\end{array}$ & \\
\hline & Less & & & $\begin{array}{l}\text { Flow decrease to the } \\
\text { tank to vacuum pump }\end{array}$ & \\
\hline & & & & $\begin{array}{l}\text { Flow decreased to } \\
\text { absorption of } \mathrm{HNO}_{3}\end{array}$ & \\
\hline & More & & $\begin{array}{l}\text { Leakage or } \\
\text { malfunction } \\
\text { of the pump to } \\
\mathrm{HNO}_{3} \\
\text { Over functioning } \\
\text { pump to } \\
\mathrm{HNO}_{3} @ 60 \%\end{array}$ & $\begin{array}{l}\text { Breaking the vacuum pump } \\
\text { Increased temperature } \\
\text { and fire hazard } \\
\text { Increased pressure within the vessel } \\
\text { Flow increase for the } \\
\text { baffle for wastewater } \\
\text { Flow increase for the tank } \\
\text { to vacuum pump }\end{array}$ & Stopping the flow \\
\hline \multirow{3}{*}{ Pressure } & Less & Flow Decreased & $\begin{array}{l}\text { Lowering the } \\
\text { temperature }\end{array}$ & $\begin{array}{c}\text { Reduced yield factor for nitration } \\
\text { Flow decreased to } \\
\text { baffle for wastewater }\end{array}$ & $\begin{array}{c}\text { Decrease Flow to } \\
\text { tank for } \mathrm{HNO}_{3} @ 60 \% \\
\text { Installation } \\
\text { of measuring } \\
\text { instrument Pressure }\end{array}$ \\
\hline & More & Flow Increase & Increasing the & $\begin{array}{l}\text { Flow increase } \\
\text { for the baffle for wastewater }\end{array}$ & $\begin{array}{l}\text { Increasing the } \\
\text { flow to the tank } \\
\mathrm{HNO}_{3} @ 60 \%\end{array}$ \\
\hline & & & temperature & Breaking the vacuum pump & $\begin{array}{c}\text { Installation } \\
\text { of measuring } \\
\text { instrument Pressure }\end{array}$ \\
\hline \multirow{5}{*}{ Temperature } & & \multirow{5}{*}{$\begin{array}{l}\text { Failed vacuum } \\
\text { filter } \\
\text { Temperature } \\
\text { change } \\
\text { in pump } \\
\mathrm{HNO}_{3} @ 60 \%\end{array}$} & \multirow{5}{*}{$\begin{array}{l}\text { Checking } \\
\text { through } \\
\text { instruments } \\
\text { (thermometer) } \\
\text { Inspection } \\
\text { through the } \\
\text { inspection } \\
\text { location }\end{array}$} & & $\begin{array}{l}\text { Decrease flow to } \\
\text { tank for } \mathrm{HNO}_{3} @ 60 \%\end{array}$ \\
\hline & $\begin{array}{c}\text { Less } \\
\left(<12^{\circ} \mathrm{C}\right)\end{array}$ & & & $\begin{array}{l}\text { Precipitation of the product } \\
\text { Vacuum pump failure }\end{array}$ & $\begin{array}{l}\text { Perform preventive } \\
\text { maintenance } \\
\text { control systems and } \\
\text { operation of feed } \\
\text { valves of the heating } \\
\text { fluid and cooling }\end{array}$ \\
\hline & & & & Over-Pressure vessels & \\
\hline & & & & $\begin{array}{l}\text { Increased speed reaction Risk of } \\
\text { explosion due to a sudden pressure }\end{array}$ & $\begin{array}{l}\text { Increasing the flow to } \\
\text { the tank } \mathrm{HNO}_{3} @ 60 \%\end{array}$ \\
\hline & $\begin{array}{c}\text { More } \\
\left(>15^{\circ} \mathrm{C}\right)\end{array}$ & & & $\begin{array}{c}\text { relief in a closed vessel } \\
\text { Leak of NOx } \\
\text { Interruption of production } \\
\text { Loss of quality } \\
\text { Yield loss } \\
\text { Risk of fire from overheating }\end{array}$ & $\begin{array}{l}\text { Perform preventive } \\
\text { maintenance on } \\
\text { control systems } \\
\text { and operation of } \\
\text { temperature control } \\
\text { valves }\end{array}$ \\
\hline
\end{tabular}

compressed air to the bottom valve, opening it (the valve fails in the open position). In case of safety valve opening, the vessel contents flow into the dump tank emergency. The tank normally is partly filled with water at room temperature. This water dilutes the acid and equalizes the temperature, thus stopping the reaction and preventing an explosion. 
Table 6. Node \#2 - Connection between nitration vessels.

\begin{tabular}{|c|c|c|c|c|c|}
\hline Guide word & Deviation & Cause & Detection & Consequences & Mitigation \\
\hline \multirow[b]{2}{*}{ Flow } & Less & \multirow{2}{*}{$\begin{array}{c}\text { Hexamine } \\
\text { feeder failure } \\
\text { Failure } \\
\text { dosage } \\
\mathrm{HNO}_{3} @ 99 \%\end{array}$} & $\begin{array}{c}\text { Decreased production of } \\
\text { the nitration vessel } 3 \\
\text { Overheating in } \\
\text { nitration vessel } 3\end{array}$ & $\begin{array}{c}\text { Interruption of } \\
\text { production downstream }\end{array}$ & $\begin{array}{c}\text { Manual duct repair } \\
\text { Replacing } \\
\text { hexamine feeder }\end{array}$ \\
\hline & More & & $\begin{array}{c}\text { Increased production of } \\
\text { the nitration vessel } 3 \\
\text { Overheating in } \\
\text { nitration vessel } 3 \\
\text { Flow in emergency } \\
\text { dump tank }\end{array}$ & $\begin{array}{l}\text { Overload nitration vessel } 3 \\
\text { Pressure and consequent } \\
\text { increased risk of explosion } \\
\text { Interruption of operation } \\
\text { of the discharge valve } \\
\text { background }\end{array}$ & $\begin{array}{c}\text { Replacing hexamine } \\
\text { feeder } \\
\text { Emptying the } \\
\text { nitration vessel } \\
\text { through bottom } \\
\text { discharge valves }\end{array}$ \\
\hline \multirow[b]{2}{*}{ Temperature } & $\begin{array}{c}\text { Less } \\
\left(<12^{\circ} \mathrm{C}\right)\end{array}$ & \multirow[b]{2}{*}{$\begin{array}{c}\text { Hexamine } \\
\text { feeder failure } \\
\text { Failure } \\
\text { dosage } \\
\mathrm{HNO}_{3} @ 99 \% \\
\text { Failure in } \\
\text { the heat } \\
\text { exchanger }\end{array}$} & $\begin{array}{l}\text { Reduction of refrigerant } \\
\text { flow return with brine } \\
\text { Checking through } \\
\text { existing instruments } \\
\text { (thermometer) }\end{array}$ & $\begin{array}{l}\text { Increased return } \\
\text { chilled water brine } \\
\text { Decreased feed flow of } \\
\text { refrigerant brine } \\
\text { Damage to the product } \\
\text { Interruption of Reaction }\end{array}$ & $\begin{array}{l}\text { Flow Decrease feed } \\
\text { coolant brine }\end{array}$ \\
\hline & $\begin{array}{c}\text { More } \\
\left(>15^{\circ} \mathrm{C}\right)\end{array}$ & & $\begin{array}{l}\text { Increasing the flow of } \\
\text { refrigerant return with } \\
\text { brine } \\
\text { Checking through } \\
\text { instruments } \\
\text { (thermometer) }\end{array}$ & $\begin{array}{c}\text { Over-Pressure vessels } \\
\text { Increased reaction speed } \\
\text { Risk of explosion due to a } \\
\text { sudden pressure relief } \\
\text { in a closed vessel } \\
\text { Leak of NOx in the workshop } \\
\text { Interruption of production } \\
\text { Loss of quality } \\
\text { Yield loss } \\
\text { Risk of fire from overheating }\end{array}$ & $\begin{array}{l}\text { Increasing flow of } \\
\text { refrigerant feed brine }\end{array}$ \\
\hline \multirow[b]{2}{*}{ Reaction } & None & \multirow{2}{*}{$\begin{array}{c}\begin{array}{c}\text { Failure } \\
\text { feeder } \\
\text { hexamine }\end{array} \\
\text { Failure } \\
\text { dosage } \\
\mathrm{HNO}_{3} @ 99 \%\end{array}$} & $\begin{array}{l}\text { Checking through } \\
\text { instruments } \\
\text { (thermometer) }\end{array}$ & $\begin{array}{l}\text { Decreased production of } \\
\text { nitrous gases } \\
\text { Overheating the first and } \\
\text { second nitration vessels }\end{array}$ & $\begin{array}{c}\text { Flow decreased to } \\
\text { the tank to discharge } \\
\text { emergency }\end{array}$ \\
\hline & More & & $\begin{array}{l}\text { Increased Pressure in the } \\
\text { first nitration vessel } \\
\text { Checking through } \\
\text { existing instruments } \\
\text { (thermometer) }\end{array}$ & $\begin{array}{l}\text { Increased rate of release of } \\
\text { nitrous gases } \\
\text { Overheating in nitration } \\
\text { vessels } 1 \text { and } 2\end{array}$ & $\begin{array}{c}\text { Flow increased to } \\
\text { the tank to discharge } \\
\text { emergency }\end{array}$ \\
\hline
\end{tabular}

Regarding the "temperature" parameter, its failures relate to issues within the feeder of hexamine, failure dosing $\mathrm{HNO}_{3} @ 99 \%$ (failure in the tank for $\mathrm{HNO}_{3} @ 99 \%$ ), and failure in the heat exchanger. The precautionary measure is to decrease or increase the flow of coolant brine according to the temperature increase or decrease, respectively. A final consideration is that, due to the nature of the reaction, a thermal explosion is very unlikely to occur, since the increase of flow would increase the rate in which NOx is released, creating an overpressure before a thermal explosion.

Analyzing the parameter "reaction", is relevant because the nitration step is essential for RDX production. In relation to this parameter, one identifies the possibility of occurrence of the following deviations: none, less and more. For them, there is a possibility of failure in nitration vessel 3 and/or nitration vessel 2 and hexamine feeder $\mathrm{HNO}_{3} @ 99 \%$ dosage failure. 
The suggested remedial measure is to regulate the flow into the tank for discharge in emergency (depending on the nature of the deviation) via regulating valves already existing.

\section{NODE \#3}

The third node (node \#3) is located between the hexamine feeder and boiler 1 . An analysis was made for flow, temperature and reaction. Table 7 is the result of the HazOp for this node.

Among the operations occurring in node \#3, there is hexamine addition into the mixture and heating in a vessel to $70^{\circ} \mathrm{C}$ (after nitration, which is carried out at $18^{\circ} \mathrm{C}$ ). This process completes the conversion of hexamine into RDX. Nitrogen oxide gases are formed as by-products. These are released to another vessel to prevent encapsulation within the crystals of $\mathrm{RDX}$ in the form of acids. Following nitration, which occurs at $18^{\circ} \mathrm{C}$, the boiler heats the mixture to $70^{\circ} \mathrm{C}$. Boiling safely completes the conversion of hexamine into RDX. Boiling also releases the nitrogen oxide gases.

The flow in this node can increase due to failures in tank RDX or $\mathrm{HNO}_{3} @ 99 \%$ Feed. Decrease of flow is related to obstruction or crushing of the supply line. The reaction parameter may be increased or decreased depending on the increase or decrease of flow equipment. As a solution to the differences observed in this node, it is suggested to carry out regular maintenance to prevent the clogging of pipelines and of feeder for hexamine, which is replaced when necessary. Another measure is that it is necessary to interrupt the operation in case of overflow.

Deviations in temperature are directly related to flow. Identification of these deviations can occur by inspection and by instruments (thermal sensors). The main consequence of temperature deviations is decrease of yield and interruption of the manufacturing process. Over-temperature increases pressure in vessels and reaction rate. Control valves and exhaust valves are required. The control valves operate integrated to sensors that measure temperature in the reactor and provide this information to a controller, which operates the valves to match set points. This safety system, if well stabilized, prevents any deviation in temperature.

Furthermore, as part of redundancy due to the explosive nature of the mix, as the temperature rises in this node, the control system enters a "state of alert". When the temperature rises to $12^{\circ} \mathrm{C}$ the Programmable Logic Controller (PLC) alerts the operator by a light in the panel, allowing the operator to monitor the situation closer. Continued increase in temperature to $15^{\circ} \mathrm{C}$ triggers a siren, thereby increasing the alertness level. At $18^{\circ} \mathrm{C}$, a bottom valve opens and discharges the contents. Dilution by water lowers the temperature, dilutes the acid thereby interrupting the reaction, and eliminates the risk of explosion. Reaction time may differ slightly due to variation in feeding hexamine and hence to temperature change in equipment (boilers). There is also a risk of losing the batch in an accidental fire.

\section{NODE \#4}

The forth node (node \#4) extends between the two boilers. Analyzed parameters are "flow", "pressure", and "temperature". Table 8 is the result of the HazOp for this node.

The reaction parameter was not considered here because there are no chemical processes before or after this node. The parameter "flow" may increase by issues in the vessel for $\mathrm{HNO}_{3} @ 99 \%$ or due to failure in the first boiler. Regarding interruption or flow reduction, there is the possibility of obstruction in the piping. To solve this problem it is suggested to implement maintenance programs and piping repair and replacement, as necessary. Deviations for flow can be identified by the presence of material in the emergency dump vessel. In this situation, the risks involved and response mechanism are analogous to those in node $\# 2$.

Pressure changes according to the flow from boiler 1 regarding the keywords "none," "less", and "more". These keywords lead to variation in the flow of cold water (feed water). To address this situation, one can establish a maintenance program for the boilers and install a pressure gauge for the control parameter. The temperature (node \#4) may increase or decrease, depending upon the decrease or increase in the pressure in boiler 1 or variations in the flow of wastewater, respectively. Temperature effects can be controlled with the implementation of instruments and a command and control system.

\section{NODE \#5}

The fifth node (node \# 5 ) is positioned between the second boiler and the second heat exchanger. Analysis of this node considers "flow", "pressure" and "temperature". Table 9 is the result of the HazOp for this node.

Like node \#4, there is no need to address the reaction parameter. No reaction occurs at this node. The parameter "flow" may be increased by faults in the tank for $\mathrm{HNO}_{3} @ 60 \%$ or because of failure in boiler 1. Flow interruption or reduction is due to obstruction in the piping, as well as the causes listed 
Table 7. Node \#3 - Connection between the nitration vessel and the boiler.

\begin{tabular}{|c|c|c|c|c|c|}
\hline Guide word & Deviation & Cause & Detection & Consequences & Mitigation \\
\hline \multirow{2}{*}{ Flow } & None & $\begin{array}{c}\text { Failure feeder } \\
\quad \text { RDX } \\
\text { Failure tank } \\
\mathrm{HNO}_{3} @ 99 \% \\
\text { Clogging the } \\
\text { duct Driving }\end{array}$ & $\begin{array}{l}\text { Overheating in boiler } \\
\text { Visual Inspection } \\
\text { Reduced flow baffle } \\
\text { for boiled water }\end{array}$ & $\begin{array}{c}\text { Damage to the boiler } \\
\text { Product loss } \\
\text { Risk of fire }\end{array}$ & $\begin{array}{l}\text { Replacing the feeder } \\
\text { for hexamine } \\
\text { Maintenance dosing } \\
\text { for hexamine } \\
\text { Duct repair manual }\end{array}$ \\
\hline & More & $\begin{array}{l}\text { Failure feeder } \\
\text { RDX } \\
\text { Failure tank } \\
\mathrm{HNO}_{3} @ 99 \%\end{array}$ & $\begin{array}{l}\text { Overheating in boiler } \\
\text { Visual Inspection } \\
\text { flow Increase for } \\
\text { boiled water baffle }\end{array}$ & $\begin{array}{c}\text { Damage to the boiler } \\
\text { Product loss }\end{array}$ & $\begin{array}{l}\text { Replacing the feeder } \\
\text { for hexamine } \\
\text { Maintenance dosing } \\
\text { for hexamine } \\
\text { Interruption of } \\
\text { proceedings }\end{array}$ \\
\hline \multirow[b]{2}{*}{ Temperature } & $\begin{array}{c}\text { Less } \\
\left(<12^{\circ} \mathrm{C}\right)\end{array}$ & $\begin{array}{l}\text { Decreased } \\
\text { flow between } \\
\text { equipment }\end{array}$ & $\begin{array}{c}\text { Verification by local } \\
\text { inspection }\end{array}$ & $\begin{array}{l}\text { Loss of income from reaction } \\
\text { Interruption of proceedings }\end{array}$ & $\begin{array}{l}\text { Use of temperature } \\
\text { control valves }\end{array}$ \\
\hline & $\begin{array}{c}\text { More } \\
\left(>15^{\circ} \mathrm{C}\right)\end{array}$ & $\begin{array}{c}\text { Increased } \\
\text { flow between } \\
\text { equipment }\end{array}$ & $\begin{array}{l}\text { Checking through } \\
\text { instruments } \\
\text { (thermometer) }\end{array}$ & $\begin{array}{c}\text { Over-pressure vessels } \\
\text { Increased speed reaction } \\
\text { Risk of explosion due to a } \\
\text { sudden pressure relief in a } \\
\text { closed vessel } \\
\text { Leak of NOx }\end{array}$ & $\begin{array}{l}\text { Use of drain valves for } \\
\text { regularization } \\
\text { Use of temperature } \\
\text { control valves }\end{array}$ \\
\hline \multirow[b]{2}{*}{ Reaction } & Less & $\begin{array}{l}\text { Failure feeder } \\
\text { RDX } \\
\text { Duct } \\
\text { obstruction } \\
\text { driving }\end{array}$ & $\begin{array}{c}\text { Cooling in } \\
\text { boilers } 1 \text { and } 2\end{array}$ & $\begin{array}{c}\text { Interruption of production } \\
\text { Loss of quality } \\
\text { Yield loss } \\
\text { System under heating }\end{array}$ & $\begin{array}{l}\text { Interrupting the } \\
\text { process to repair } \\
\text { feeder in }\end{array}$ \\
\hline & More & $\begin{array}{c}\text { Failure feeder } \\
\text { RDX }\end{array}$ & $\begin{array}{l}\text { Heating in } \\
\text { boilers } 1 \text { and } 2\end{array}$ & $\begin{array}{c}\text { Interruption of production } \\
\text { Loss of quality } \\
\text { Yield loss } \\
\text { Risk of fire from overheating } \\
\text { Leak of NOx in the workshop }\end{array}$ & $\begin{array}{l}\text { Interrupting the } \\
\text { process to repair } \\
\text { feeder RDX }\end{array}$ \\
\hline
\end{tabular}

for flow increase. Dosing accurately the hexamine can mitigate both deviations.

Pressure at node \#5 varies due to gas leakage. This is a case of pressure reduction, which may be caused by an increase in the generation of nitrogen oxide gases, as well as a decrease in the capability of releasing pressure. Thus, there must be a pressure gauge at this point, and a pressure relief valve and enabling the discharge of nitrogen oxide gases.

The increase or decrease in temperature at this point (node \#5) is related to decreased pressure or reduced inflow of cold water in the heat exchanger, as well as an increase in the pressure and inflow of cold water in the heat exchanger, respectively. These variations relates to the variation in the return flow of cooling water feed, as well as the flow of coolant water. The consequences of temperature increase at this point (node \#5) do not generate events with potential major accidents or explosions, but can produce burns in the case of leakage. Inspection routines or changing the system for the return flow of chilled water and cold water feed will control temperature deviations.

\section{NODE \#6}

The sixth node (node\#6) is located between the heat exchanger and vacuum filters. To study this node, the recommended parameters are "flow" and "temperature", since there is no 
Table 8. Node \#4 - Connection between boilers.

\begin{tabular}{|c|c|c|c|c|c|}
\hline Guide word & Deviation & Cause & Detection & Consequences & Mitigation \\
\hline \multirow[b]{2}{*}{ Flow } & None & $\begin{array}{l}\text { Failure at first } \\
\text { boiler } \\
\text { Failure tank } \\
\mathrm{HNO}_{3} @ 99 \% \\
\text { Duct } \\
\text { obstruction in } \\
\text { driving }\end{array}$ & $\begin{array}{l}\text { Interruption of the } \\
\text { production process } \\
\text { Under heating the } \\
\text { boiler } 2 \\
\text { Reduction of flow baffle } \\
\text { for wastewater }\end{array}$ & $\begin{array}{c}\text { Loss of production quality } \\
\text { due to the contribution } \\
\text { of the advancement of } \\
\text { chilled water }\end{array}$ & $\begin{array}{c}\text { Maintenance } \\
\text { first boiler } \\
\text { Maintaining the tank } \\
\text { HNO3@99\% } \\
\text { Duct repair manual }\end{array}$ \\
\hline & More & $\begin{array}{c}\text { Failure boiler } 1 \\
\text { Failure tank } \\
\mathrm{HNO}_{3} @ 99 \%\end{array}$ & $\begin{array}{l}\text { Interruption of the } \\
\text { production process } \\
\text { Overheating the boiler } 2 \\
\text { Flow presence of } \\
\text { the boiler } 1 \text { to the } \\
\text { emergency dump tank } \\
\text { Flow Increase for the } \\
\text { baffle wastewater }\end{array}$ & $\begin{array}{c}\text { Insufficient progress } \\
\text { chilled water to } \\
\text { maintain operations } \\
\text { Interruption of operation } \\
\text { of the discharge valve } \\
\text { background }\end{array}$ & $\begin{array}{c}\text { Maintenance } \\
\text { first boiler } \\
\text { Maintaining the tank } \\
\text { HNO3@99\% }\end{array}$ \\
\hline \multirow[t]{2}{*}{ Pressure } & Less & $\begin{array}{l}\text { Decreased flow } \\
\text { at first boiler }\end{array}$ & $\begin{array}{l}\text { Interruption of the } \\
\text { production process } \\
\text { Verification by } \\
\text { instruments } \\
\text { Breaking duct driving }\end{array}$ & $\begin{array}{l}\text { Decreased Flow for the } \\
\text { heat exchanger } \\
\text { Increased feed } \\
\text { of cold water }\end{array}$ & $\begin{array}{c}\text { Maintenance } \\
\text { first boiler } \\
\text { Installing a meter or } \\
\text { pressure gate } \\
\text { Installation and }\end{array}$ \\
\hline & More & $\begin{array}{l}\text { Increased flow } \\
\text { at first boiler }\end{array}$ & $\begin{array}{l}\text { Checking through } \\
\text { the instruments } \\
\text { consolidated control } \\
\text { panel unit }\end{array}$ & $\begin{array}{l}\text { Risk of explosion due to a } \\
\text { sudden pressure relief } \\
\text { in a closed vessel }\end{array}$ & $\begin{array}{l}\text { calibration of } \\
\text { Pressure relief valves } \\
\text { are configured as } \\
\text { recommended in } \\
\text { regulations }\end{array}$ \\
\hline \multirow{2}{*}{ Temperature } & $\begin{array}{c}\text { Less } \\
\left(<12{ }^{\circ} \mathrm{C}\right)\end{array}$ & $\begin{array}{l}\text { Decreased } \\
\text { Pressure on } \\
\text { boiler } 1 \\
\text { Flow Increase } \\
\text { for the baffle for } \\
\text { wastewater }\end{array}$ & \multirow{2}{*}{$\begin{array}{l}\text { Verification by local } \\
\text { inspection } \\
\text { Checking through } \\
\text { instruments } \\
\text { (thermometer) } \\
\text { Verification flow } \\
\text { to the baffles }\end{array}$} & $\begin{array}{l}\text { Decrease in advance } \\
\text { of cold water } \\
\text { Increase in reaction time } \\
\text { Reduced yield factor }\end{array}$ & \multirow{2}{*}{$\begin{array}{c}\text { Installation of control } \\
\text { valves temperature } \\
\text { Installation flush } \\
\text { valves bottom }\end{array}$} \\
\hline & $\begin{array}{c}\text { More } \\
\left(>15^{\circ} \mathrm{C}\right)\end{array}$ & $\begin{array}{l}\text { Increased } \\
\text { Pressure in the } \\
\text { kettle } 1 \\
\text { Flow decreased } \\
\text { to baffle for } \\
\text { wastewater }\end{array}$ & & $\begin{array}{l}\text { Risk of explosion due to a } \\
\text { sudden pressure relief in a } \\
\text { closed vessel } \\
\text { Risk of Explosive initiation }\end{array}$ & \\
\hline
\end{tabular}

chemical reaction near this node. It remains at atmospheric pressure. Table 10 is the result of the HazOp for this node.

Flow (at node \#6) can increase due to a failure in the heat exchanger, a failure in the tank to $\mathrm{HNO}_{3} @ 60 \%$. Due to the absence of reaction, any flow issue relates to a failure in the tank and/or an obstruction in the flow driving. The consequence of these deviations is the changing of the load on the vacuum filter (increase, decrease or lack of flow).
Correction of deviations to flow requires installation of a flow control valve between equipment, periodic maintenance and a flow meter in the piping. Maintenance is a critical aspect for this node as well as the previous nodes. Further analysis of deviation in temperature at node \#6 indicates that it relates to changes in the flow of cold water. Installing equipment for monitoring as well as for cooling or heating the product to be filtered can control these deviations. 
Table 9. Node \#5 - Connection between boiler and heat exchanger.

\begin{tabular}{|c|c|c|c|c|c|}
\hline Guide word & Deviation & Cause & Detection & Consequences & Mitigation \\
\hline \multirow[t]{2}{*}{ Flow } & None & $\begin{array}{l}\text { Failure in } \\
\text { the tank for } \\
\mathrm{HNO}_{3} @ 60 \% \\
\text { Failure in the } \\
\text { first boiler } \\
\text { Duct } \\
\text { obstruction in } \\
\text { driving }\end{array}$ & $\begin{array}{l}\text { Under heating of the } \\
\text { heat exchanger }\end{array}$ & $\begin{array}{l}\text { Pressure decrease the heat } \\
\text { exchanger } \\
\text { Heating in the heat exchanger }\end{array}$ & $\begin{array}{l}\text { Increasing the } \\
\text { flow of feedstock } \\
\text { feeder RDX }\end{array}$ \\
\hline & More & $\begin{array}{l}\text { Failure in } \\
\text { the tank for } \\
\mathrm{HNO}_{3} @ 60 \% \\
\text { Failure in the } \\
\text { first boiler }\end{array}$ & $\begin{array}{l}\text { Overheating of the } \\
\text { heat exchanger }\end{array}$ & $\begin{array}{l}\text { Increased Pressure } \\
\text { in the heat exchanger } \\
\text { Cooling Heat Exchanger }\end{array}$ & $\begin{array}{l}\text { Reducing the flow of } \\
\text { raw material in the } \\
\text { feeder RDX }\end{array}$ \\
\hline \multirow{3}{*}{ Pressure } & None & Gas Leak & Visual inspection & Interruption of production & \multirow{3}{*}{$\begin{array}{l}\text { Installing a meter at } \\
\text { this point Pressure } \\
\text { Installing a valve } \\
\text { for controlling the } \\
\text { output of nitrous } \\
\text { gases at this point }\end{array}$} \\
\hline & Less & $\begin{array}{l}\text { Increased of } \\
\text { NOx output }\end{array}$ & $\begin{array}{l}\text { Checking through } \\
\text { instruments (Pressure } \\
\text { gauge) or control panel } \\
\text { operating parameters } \\
\text { Decrease the } \\
\text { temperature in the heat } \\
\text { exchanger }\end{array}$ & $\begin{array}{l}\text { Ineffectiveness of heat } \\
\text { exchange, compromising the } \\
\text { yield and economic } \\
\text { balance of reaction }\end{array}$ & \\
\hline & More & $\begin{array}{l}\text { Decreased } \\
\text { output of } \\
\text { nitrous gases }\end{array}$ & $\begin{array}{l}\text { Visual inspection } \\
\text { Checking through } \\
\text { instruments (Pressure } \\
\text { gauge) or control panel } \\
\text { operating parameters } \\
\text { Increased temperature } \\
\text { in the heat exchanger }\end{array}$ & $\begin{array}{l}\text { Risk of explosion due to a } \\
\text { sudden pressure relief in a } \\
\text { closed vessel }\end{array}$ & \\
\hline \multirow{2}{*}{ Temperature } & $\begin{array}{c}\text { Less } \\
\left(<60^{\circ} \mathrm{C}\right)\end{array}$ & $\begin{array}{l}\text { Decreased } \\
\text { pressure } \\
\text { Reduction } \\
\text { of flow entry } \\
\text { of cold water } \\
\text { in the heat } \\
\text { exchanger }\end{array}$ & $\begin{array}{l}\text { Verification by local } \\
\text { inspection } \\
\text { Checking through } \\
\text { instruments } \\
\text { (thermometers) } \\
\text { Reduction of flow } \\
\text { chilled water return } \\
\text { flow increase in feed } \\
\text { cold water }\end{array}$ & $\begin{array}{c}\text { Ineffectiveness of heat } \\
\text { exchange, compromising the } \\
\text { yield and economic balance } \\
\text { of reaction }\end{array}$ & \multirow{2}{*}{$\begin{array}{l}\text { Use valve for } \\
\text { controlling the } \\
\text { water outlet from } \\
\text { the cold heat } \\
\text { exchanger }\end{array}$} \\
\hline & $\begin{array}{c}\text { More } \\
\left(>80^{\circ} \mathrm{C}\right)\end{array}$ & $\begin{array}{l}\text { Increased } \\
\text { pressure } \\
\text { Flow of } \\
\text { increased cold } \\
\text { water inlet } \\
\text { in the heat } \\
\text { exchanger }\end{array}$ & $\begin{array}{l}\text { Verification by local } \\
\text { inspection } \\
\text { Checking through } \\
\text { instruments } \\
\text { (thermometers) } \\
\text { Increasing the flow of } \\
\text { chilled water return } \\
\text { Decreased feed flow } \\
\text { cold water }\end{array}$ & $\begin{array}{l}\text { There is no risk of explosion, } \\
\text { just leak fluid heated, which } \\
\text { creates potential for burns }\end{array}$ & \\
\hline
\end{tabular}


Table 10. Node \#6 - Connection between the heat exchanger and the vacuum filter.

\begin{tabular}{|c|c|c|c|c|c|}
\hline Guide word & Deviation & Cause & Detection & Consequences & Mitigation \\
\hline \multirow[t]{2}{*}{ Flow } & None & $\begin{array}{l}\text { Mechanical failure in } \\
\text { the heat exchanger } \\
\text { Failure in the tank for } \\
\mathrm{HNO}_{3} @ 60 \% \\
\text { Duct obstruction } \\
\text { driving }\end{array}$ & $\begin{array}{l}\text { Decreasing the } \\
\text { amount of produced } \\
\text { hexogen }\end{array}$ & $\begin{array}{l}\text { Under load in } \\
\text { the vacuum filter }\end{array}$ & $\begin{array}{c}\text { Regular benchmarking of } \\
\text { verification of } \\
\text { equipment (meter) } \\
\text { Installing a control } \\
\text { valve flow } \\
\text { Duct repair }\end{array}$ \\
\hline & More & $\begin{array}{l}\text { Mechanical failure in } \\
\text { the heat exchanger } \\
\text { Failure in the tank for } \\
\text { HNO @60\% }\end{array}$ & $\begin{array}{l}\text { Increasing the amount } \\
\text { of produced hexogen } \\
\text { Identification of } \\
\text { overflow material }\end{array}$ & $\begin{array}{l}\text { Overhead in the } \\
\text { vacuum filter }\end{array}$ & $\begin{array}{l}\text { Regularization of flow } \\
\text { through safety valves } \\
\text { Performing batch filtering }\end{array}$ \\
\hline \multirow{2}{*}{ Temperature } & Less & $\begin{array}{l}\text { Flow decrease } \\
\text { in cold water }\end{array}$ & $\begin{array}{l}\text { Verification by local } \\
\text { inspection }\end{array}$ & $\begin{array}{l}\text { Interruption of } \\
\text { operation } \\
\text { of the filter }\end{array}$ & $\begin{array}{l}\text { Establish procedures } \\
\text { and regular targets for } \\
\text { maintenance of existing } \\
\text { control systems }\end{array}$ \\
\hline & More & $\begin{array}{l}\text { Flow increase } \\
\text { in cold water }\end{array}$ & $\begin{array}{l}\text { Checking through } \\
\text { instruments } \\
\text { (thermometer) }\end{array}$ & $\begin{array}{l}\text { Interruption of } \\
\text { operation } \\
\text { of the filter } \\
\text { Damage to } \\
\text { the filter }\end{array}$ & $\begin{array}{l}\text { Installing a hardware } \\
\text { check (thermometer) } \\
\text { Interrupting the natural } \\
\text { cooling process } \\
\text { for product }\end{array}$ \\
\hline
\end{tabular}

\section{NODE \#7}

The seventh node (node \# 7) is located between the vacuum filters and the output of RDX. Flow is the only relevant parameter here since there is no chemical reaction and the flux between filters connection and product exit occurs in atmospheric pressure. Table 11 is the result of the $\mathrm{HazOp}$ for this node.

The parameter, "flow", indicates the failure of production in previous equipment, which is critical in this node. In order to identify the causes of deviation in the flow, one uses the keywords "none," "less", and "more". As a general rule, all deviation in flow relates to failure in vacuum filters (clogged or damaged) or obstruction of piping. Deviations for this node (node \#7) are observable through loss of product quality and operational variation of the exhaust system. A possible mitigation is to ensure maintenance of this equipment.

\section{DISCUSSION}

Addressing the $\mathrm{HazOp}$ results from a management perspective, operation of the control system around the same variables and set points is critically important. This starting point provides the means to observe and address all possible (and sometimes expected) deviations. This integrated unit could be a PLC panel that monitors and controls all parameters relevant to the operation (temperature, pressure and flow rates).

Deviations in temperature are controllable through valves and/or temperature control equipment. In the RDX manufacturing unit, these valves should be installed along the pipeline to ensure safety.

A possible suggestion for improvement of in-service units is to modernize the existing control panel to ensure the most 
Table 11. Node \#7 - Connection between the vacuum filter and the RDX recovery pan.

\begin{tabular}{|c|c|c|c|c|c|}
\hline $\begin{array}{l}\text { Guide } \\
\text { word }\end{array}$ & Deviation & Cause & Detection & Consequences & Mitigation \\
\hline \multirow{3}{*}{ Flow } & None & & \multirow{3}{*}{$\begin{array}{c}\text { Visual Inspection } \\
\text { Verification of the final product } \\
\text { - not or poorly crystallized } \\
\text { Flow Increase for the tank } \\
\mathrm{HNO}_{3} @ 60 \%\end{array}$} & \multirow{2}{*}{$\begin{array}{l}\text { Low yield factor } \\
\text { Under } \\
\text { functioning } \\
\text { the hood }\end{array}$} & Repair of vacuum filters \\
\hline & Less & $\begin{array}{l}\text { Clogging the duct } \\
\text { Driving }\end{array}$ & & & $\begin{array}{l}\text { Maintenance or } \\
\text { replacement duct } \\
\text { Driving }\end{array}$ \\
\hline & More & Failure in vacuum filters & & $\begin{array}{l}\text { Low yield factor } \\
\text { Over functioning } \\
\text { the hood }\end{array}$ & $\begin{array}{l}\text { Maintenance or } \\
\text { replacement duct } \\
\text { Driving }\end{array}$ \\
\hline
\end{tabular}

accurate levels of control. However, this intervention would require readjustment of the major part of the unit, making this option costly and sometimes financially unviable.

During the study, some safety bypasses were plotted, but neglected for HazOp purposes. Usually a bypass is located in stretches of critical piping and valves between departure and arrival of fluids. These safety devices ensure operational continuity of flow since they provide an alternate path for process fluids. They are, therefore, vital to solving the identified deviations in the parameter, "flow". This statement allows one to conclude that design engineers addressed the same issues discussed in this paper.

Data loggers found in most RDX units offer redundant storage of measurements in addition to storage devices present in the control panel.

In the storage vessels, one solution to the problem of deviations in the flow is an emergency discharge system. In the first node, for example, in case of failure there is the alternative of pumping fluid into the $\mathrm{HNO}_{3}$ vessel. This will stop the process and reaction bulk would flow into the tank that contains $\mathrm{HNO}_{3} @ 60 \%$.

Furthermore, from the analysis of the design of an RDX manufacturing unit, one should conclude that some equipment provides redundancy, most likely for predicting the occurrence of failures as discussed in this paper. Action taken as a result of this analysis ensures, in some cases, the continuity of the process and in others, safe termination.

Since many of the control measures suggested in response to the possible consequences listed in this study are already present in most RDX plants, there is the logical assumption that a HazOp-type study has occurred prior to project implementation. However, absence of documentation of such studies in the open literature increases the relevance of this paper.
RDX manufacturing plants usually contain pneumatically controlled and powered equipment. This requires a source of compressed air. The compressed air system was not addressed as part of this work.

Installation of electronic sensing and control devices in RDX plants should increase accuracy and precision of operational parameters. However, these devices will not guarantee greater reliability in the safety system. Bottom valves, due to pneumatic operation and control, must remain in the CLOSED position during operation and fail in the OPEN position. This increases safety, since any loss of energy (or another deviation) will cause the valve to open, thereby discharging the reacting material into the dump vessel.

Most RDX units contain PLCs to monitor and control operating parameters. These communication systems allow the transmission of broadband data through the electrical grid. Thus would be allowed to monitor the unit for any computer, provided they are properly authorized, through Internet, favoring the monitoring of security conditions. Another advantage of the system is that its implementation requires no physical alterations on site, once the grid is already in place.

\section{CONCLUSION}

This paper assessed the risks of operation of an RDX manufacturing unit using $\mathrm{HazOp}$ methodology. This paper focused on the core issues of such a manufacturing unit, since the nodes were applied only at seven points, considered critical to the overall operation. Upon conclusion of this particular $\mathrm{HazOp}$, each node provided key information that should be 
Table 12. Study contributions and final results.

\begin{tabular}{l|l|l} 
Node & Node description & Key equipment
\end{tabular}

Array of vessels for

1 waste and clean water for dilute $\mathrm{HNO}_{3}$

2

Connection between nitration vessels

Nitration vessel

Connection between

3

the nitration vessel and the boiler

Post-nitration boiler Connection between
boilers

Boiler

Connection between boiler and heat exchanger

Heat exchanger

Connection between

6

the heat exchanger and the vacuum filter

Connection between

Vacuum filter

Filtering system the vacuum filter and the RDX recovery pan

\section{Recommendations}

Installation of control valves to assure flow management.

Implementation of level and temperature instruments.

All instrumentation should be integrated.

Implementation of a system to dose hexamine automatically

Installation of a venting system in the equipment to prevent overpressure and the consequent risk of explosion is recommended.

Use of an empty dump tank and a draining valve at bottom. Favor mechanical valves over electronic ones in this key position.

This operation (boiling) will release the nitrogen oxide gases, requesting a venting/exhaustion system.

It is necessary a mechanism to interrupt the operation in case of overflow.

Deviations in temperature are directly related to flow.

Deviations for flow can be identified by the presence of material in the emergency dump vessel. In this situation the risks involved and response mechanism are analogous to those in node \#2.

Installation of a pressure gauge for the control parameter.

Temperature effects should be controlled with the implementation of instruments and a command and control system.

Dosing accurately the hexamine is key to avoid deviations in flow and temperature.

This operation (boiling) will release the nitrogen oxide gases, requesting a venting/exhaustion system.

Installation of control valves and periodic maintenance, as well as a flow meter should be considered

Installing equipment for monitoring as well as for cooling or heating the product to be filtered should be considered

Deviations for this node (node \#7) are observable through loss of product quality and operational variation of the exhaust system.

A possible mitigation is to ensure maintenance of this equipment.

considered when designing or operating any RDX nitration unit. Those key aspects are consolidated in Table 12.

Furthermore, the results show that the guidewords used for selected nodes (flow, pressure, temperature and reaction) and their deviations made possible a complete diagnostic of the RDX nitration unit intrinsic risks. This approach also made possible the analysis of types of detection, consequences of failure, and steps to be taken for each deviation identified.
This study also indicates that a risk assessment had occurred on the unit examined in this study previously. This is evident mainly due to existence in the flowcharts of the required mitigation measurements (such as safety valves, bypasses and control instruments). Finally, it is important to mention that HazOp methodology does not quantify risk. For this reason, other tools for risk assessment should complement HazOp. 


\section{REFERENCES}

Achuthan, C.P. and Mullick, G., 1983, "Hazards in the manufacture of RDX and HMX", Defence Science Journal, Vol. 33, No. 1, pp. 91-95.

Akhavan, J., 2011, "The Chemistry of Explosives", Third Ed., Norfolk: Biddles Ltd., Kings Lynn, Norfolk.

Aven, T., २०12, "On the critique of Beck's view on risk and risk analysis", Safety Science, Vol. 50, No. 4, pp. 1043-1048. doi:10.1016/j.ssci.2011.12.004.

Bachmann, W.E. and Sheehan, J.C., 1949, "A new method of preparing the high explosive RDX", Journal of the American Chemical Society, Vol. 71, No. 5, pp. 1842-1845. doi: 10.1021/ ja01173a092.

Bisarya, R.K. and Puri, S., 2005, "The Bhopal gas tragedy - A perspective", Journal of Loss Prevention in the Process Industries, Vol. 18, No. 4-6, pp. 209-212. doi:10.1016/j.jp.2005.07.006.

Boonthum, N., Mulalee, U. and Srinophakun, T., 2014, "A systematic formulation for HAZOP analysis based on structural model", Reliability Engineering \& System Safety, Vol. 121, pp. 152-163. doi:10.1016/j. ress.2013.08.008.

van den Bosch, C.J.H. and Weterings, R.A.P.M., 2005, "Yellow Book" - CPR 14E - Methods for the calculation of Physical Effects. Third ed. [S.I.]: Committee for the Prevention of Disasters.

CCPS, 1989, "Guidelines for Chemical Process Quantitative Risk Analysis", CCPS - CEN ed. New York: Center for Chemical Process Safety of the American Institute of Chemical Engineers.

Chouhan, T.R., 2005, "The unfolding of Bhopal disaster", Journal of Loss Prevention in the Process Industries, Vol. 18, No. 4-6, pp. 205208. doi:10.1016/j.jp.2005.07.025.

Cooper, P.,1996, "Explosives Engineering", [S.I.]: Wiley-VCH, Inc. United States of America.

Crawley, F., Preston, M. and Tyler, B., 2000, "Hazop: Guide to best practice. Guidelines to best practice for the process and chemical industries", [S.I.]: Institution of Chemical Engineers (Great Britain), European Process Safety Centre. United Kingdom: The Cromwell Press.

Defence, D.D., 2012, "MIL STD 882-E - Standard Practice for System Safety".

Dunjó, J., Fthenakis, V., Villchez, J.A. and Arnaldos, J., 2010, "Hazard and operability (HAZOP) analysis. A literature review", Journal of hazardous materials, Vol. 173, No. 1-3, pp. 19-32. doi:10.1016/j. jhazmat.2009.08.076.

Eckerman, I., 2005, "The Bhopal gas leak: Analyses of causes and consequences by three different models", Journal of Loss Prevention in the Process Industries", Vol. 18, No. 4-6, pp. 213-217. doi:10.1016/j.jp.2005.07.007.

Fogler, H., 1999, "Elements of chemical reaction engineering", [S.I: s.n.].

Freeman, K., Lee, R. and Mcnamara, T., 1992, "Plan HAZOP studies with an expert system", Chemical Engineering Progress, Vol. 88, No. 8, pp. 28-32.

Galante, E.B.F., Boer, A.H.D. and Bonifácio, D., 2014, "Life Cicle Inventory for Lead Azide Manufacture", Journal of Aerospace Technology and Management, Vol. 6, No. 1, pp. 53-60. doi:10.5028/jatm.v6i1.289.

Galante, E. and Haddad, A., 2009, "Risk analysis procedures for explosives manufact ... Advances in Safety, Reliability and Risk
Management", Proceedings of the European Safety and Reliability Conference, ESREL 2009. [S.I: s.n.], p. 2009.

Galante, E., Haddad, A. and Marques, N., 2013, "Application of Explosives in the Oil Industry", International Journal of Oil, Gas and Coal Engineering (OGCE), Vol. 1, No. 2, pp. 16-22. doi:10.11648/j. ogce.20130102.11.

Gehlawat, J.K., 2005, "Bhopal disaster - a personal experience", Journal of Loss Prevention in the Process Industries, Vol. 18, No. 4-6, pp. 261-263. doi:10.1016/j.jp.2005.07.002.

Graf, H. and Schmidt-Traub, H., 2000, "Early hazard identification of chemical plants with statechart modelling techniques", Safety science, Vol. 36, No, 1, pp.49-67. doi: 10.1016/S0925-7535(00)00034-5.

Haddad, A., Galante, E., Caldas, R. and Morgado, C., 2012 "Hazard Matrix Application in Health, Safety and Environmental Management Risk Evaluation". InTech. [S.I: s.n.]. doi: 10.5772/17159.

Held, M., 2012, "Explosion in an HMX (octogen) plant", In: AICHE ANNUAL MEETING. Anais... [S.I: s.n.].

IMBEL, 2006, "IMBEL", Retrieved in July 17, 2013, from www.imbel. gov.br

Júnior, J.B.C., 2002, "Metodologia de Análise de Risco em Sistemas Computacionais de Aplicação Crítica", Escola Politécnica da Universidade de São Paulo - [S.I.].

Kennedy, R. and Kirwan, B., 1998, "Development of a Hazard and Operability-based method for identifying safety management vulnerabilities in high risk systems", Safety Science, Vol. 30, No. 3, pp. 249-274. doi:10.1016/S0925-7535(98)00025-3.

Khan, F.I. and Abbasi, S.A., 1999, "Major accidents in process industries and an analysis of causes and consequences", Journal of Loss Prevention in the Process Industries, Vol. 12, No. 5, pp. 361378. doi:10.1016/S0950-4230(98)00062-X

Khan, F.I. and Abbasi, S.A., 1997, "Tophazop: a knowledge-based software tool for conducting HAZOP in a rapid, efficient yet inexpensive manner", Journal of Loss Prevention in the Process Industries, Vol. 10, No. 5-6, pp. 333-343.

Kletz, T., 2009, "What Went Wrong?, Fifth Edition: Case Histories of Process Plant Disasters and How They Could Have Been Avoided", 5th. ed. Oxford, UK: Elsevier Inc.

Labovský, J., Svandová, Z., Markos, J. and Jelemenský, L., 2007, "Model-based HAZOP study of a real MTBE plant", Journal of Loss Prevention in the Process Industries, Vol. 20, No. 7, pp. 230-237. doi: 10.1016/j.jp.2007.03.015.

Leach, J.T. and Staples, J.M., 1981, "Hazards of inadvertent mixing of chemicals used in the Bachmann processes for manufacturing the military explosives RDX and HMX", Journal of Hazardous Materials, Vol. 4, No. 3, pp. 271-281. doi:10.1016/03043894(81)80005-2.

Lukasavage, W.J. and Slagg, N., 1993, "Process for preparation of RDX. n. Patent number US5250687", International Classification: C07D25106.

Mei, Z., Qian, H., Liu, D., Ye, Z. and Lü, C., 2012, "Preparation of emulsion explosive for military-civil", Huozhayao Xuebao/Chinese Journal of Explosives and Propellants, Vol. 35, No. 1, pp. 32-34. 
Meredith, J.A., 1976, "Preparation of RDX". n. [s.n.].

Meyer, R., Köhler, J. and Homburg, A., 2007, "Explosives". 6th, Compl. ed. Weinheim: Wiley-VCH Verlag GmbH, Weinheim.

Pérez-Marín, M. and Rodríguez-Toral, M.A., 2013, "HAZOP - Local approach in the Mexican oil \& gas industry", Journal of Loss Prevention in the Process Industries, Vol. 26, No. 5, pp. 1-5. doi:10.1016/j. jlp.2013.03.008.

Rausand, M. and Hoyland, A., 2011, "HAZOP - Hazard and Operability Study. System Reliability Theory", Models, Statistical Methods and Applications. Second Edi ed. New York: John Wiley \& Sons.

Rausand, M. and Utne, I.B., 2009, "Product safety - Principles and practices in a life cycle perspective", Safety Science, Vol. 47, No. 7, pp. 939-947. doi:10.1016/j.ssci.2008.10.004.

Rossing, N.L., Lind, M., Jensen, N and Jørgensen, S.B., 2010, "A functional HAZOP methodology", Computers \& Chemical Engineering, Vol. 34, No. 2, pp. 244-253. doi:10.1016/j. compchemeng.2009.06.028.

Rouhiainen, V. and Gunnerhed, M., 2002, "Development of international risk analysis standards", Safety Science, Vol. 40, No. 1-4, pp. 57-67. doi:10.1016/S0925-7535(01)00034-0.

Sahar, N.B.M., Ardi, S., Kazuhiko, S., Yoshiomi, M. and Hirotsugu, M., 2010, "HAZOP analysis management system with dynamic visual model aid", American Journal of Applied Sciences, Vol. 7, No. 7, pp. 930-935.
Schüller, J.C.H., Brinkman, J.L., Van Gestel, P.J. and van Otterloo, R.W., 1997, "Red Book" - CPR 12E - Methods for determiming and processing probabilities, Netherlands: CPR 12 E - Committee for Prevention of Disasters.

Seccatore, J., Origliasso, C. and Tomi, G., 2013, "Assessing a risk analysis methodology for rock blasting operations", In: Paper Presented at the Blasting in Mines - New Trends: Workshop Hosted by Fragblast 10 - The 10th International Symposium on Rock Fragmentation By Blasting. Anais... [S.I: s.n.].

Shimada, Y., Kitajima, T. and Ling, Y., 2012, "Integrated risk management system based on IPL concept for chemical processes", In: 11th International Probabilistic Safety Assessment and Management Conference and The Annual European Safety and Reliability Conference 2012, PSAM11 ESREL 2012,. Anais... [S.I: s.n.].

Steen, R. and Aven, T., 2011, "A risk perspective suitable for resilience engineering", Safety Science, Vol. 49, No. 2, pp. 292-297. doi:10.1016/j.ssci.2010.09.003.

Taylor, J.R., 2007, "Understanding and combating design error in process plant design”, Safety Science, Vol. 45, No. 1-2, pp. 75-105. doi:10.1016/j.ssci.2006.08.014.

Urbanski, T., 1984, "Chemistry and tecnology of explosives", Vol 4. New York, USA: Pergamon Press. 